\title{
PENGARUH KONSENTRASI ZAT PENSTABIL DAN JENIS KUNING TELUR TERHADAP MUTU REDUCED FAT MAYONNAISE
}

The Effect of Stabilizer Concentration and Type of Egg Yolk on The Quality of Reduced Fat Mayonnaise

\author{
Indah Prabawati ${ }^{1,}$ Akhmad Mustofa ${ }^{1}$, Yustina Wuri Wulandari ${ }^{1}$ \\ ${ }^{1}$ Fakultas Teknologi dan Industri Pangan Universitas Slamet Riyadi Surakarta, \\ Jl. Sumpah Pemuda 18 Joglo Kadipiro Surakarta 57136 \\ E-mail: yustinawulandari@yahoo.co.id
}

\begin{abstract}
ABSTRAK
Mayones merupakan produk olahan telur yang memiliki kandungan lemak tinggi. Reduce fat mayonnaise merupakan salah satu jenis mayones yang memiliki kadar lemak rendah dibandingkan full fat mayonnaise. Penelitian dilakukan dengan menggunakan Rancangan Acak Lengkap (RAL) faktorial yang terdiri dari dua faktor. Faktor pertama jenis zat penstabil dengan berbagai konsentrasi CMC 2,06\%, Maltodekstrin 82,43\%, Xanthan gum $3,09 \%$. Faktor kedua jenis kuning telur dengan konsentrasi setiap bahan 20,60\% yaitu kuning telur ayam kampung, kuning telur ayam petelur, kuning telur ayam omega 3 . Hasil penelitian ini menunjukkan bahwa perlakuan kombinasi yang mempunyai kadar lemak lebih rendah yaitu zat penstabil maltodekstrin $82,43 \%$ dengan kuning telur ayam omega 3 dengan konsentrasi 20,60\% kombinasi perlakuan tersebut mengandung kadar air 28,651\%, kadar lemak 45,650\%, pH 4,5, viskositas 3,30 Pa.s, kadar gula total 0,897\%, kadar protein $0,160 \%$. Pada pengujian organoleptik yaitu warna putih kekuningan $(3,3)$, tekstur lembut $(3,97)$, tekstur creamy $(3,46)$, kesukaan keseluruhan (paling disukai) $(2,6)$, flavor (mayonnaise) $(3,21)$. Pada penelitian ini kadar lemak masih cukup tinggi sehingga belum mencapai tujuan dari pembuatan reduce fat mayonnaise
\end{abstract}

Kata kunci : Mayones, reduce fat mayonnaise, kuning telur ayam, zat penstabil

\begin{abstract}
Mayonnaise is an processed egg product that has a high fat content. Reduce fat mayonnaise is one type of mayonnaise that has lower fat content compared to full fat mayonnaise. The study was conducted using a factorial Completely Randomized Design (CRD) consisting of two factors. The first factor was the type of stabilizer with $2.06 \%$ of CMC, $82.43 \%$ of maltodextrin and $3.09 \%$ of xanthan gum. The second factor was the type of egg yolk with $20.60 \%$ concentration of each ingredient, free range chicken egg yolk, broiler chicken egg yolk, omega 3 chicken egg yolk. The results of this study indicate that the combination treatment which has lower fat content was $82.43 \%$ of maltodextrin with omega 3 chicken egg yolk of $20.60 \%$. The treatment combination contains $28.651 \%$ of water content, $45.650 \%$ of fat content, $\mathrm{pH} 4.5$, viscosity 3.30 Pa.s, total sugar content of $0.897 \%$, protein content of $0.160 \%$. In organoleptic testing, they are color (yellowish white) (3.3), soft texture (3.97), creamy texture $(3,46)$, overall preference (most preferred) (2.6), flavor mayonnaise
\end{abstract}


(3.21). The result of study the fat content was still high so that it has not reached the goal of reduced fat mayonnaise.

Keywords: Mayonnaise, reduce fat mayonnaise, chicken egg yolk, stabilizing agent

\section{PENDAHULUAN}

Reduce fat mayonnaise merupakan salah satu jenis mayones yang memiliki kadar lemak rendah dibandingkan full fat mayonnaise. Namun, kadar air dari reduce fat mayonnaise lebih banyak sehingga perlu ditambahkan stabilizer agar emulsi tetap stabil. Stabilitas emulsi pada mayones tergantung pada jumlah minyak yang digunakan, jumlah kuning telur, metode pengocokan, temperatur, dan bahan tambahan lainnya (Harrison \& Cunningham, 1985). Bahan-bahan yang dapat digunakan sebagai emulsifier antara lain protein hewani seperti protein whey, kasein, protein daging, dan protein nabati seperti kedelai, bunga matahari, dan tepung lupin (Raymundoa, Franco, Empis \& Sousa, 2002).

Kuning telur memiliki kandungan kolesterol yang cukup tinggi sehingga banyak orang yang menghindarnya. Kuning telur memang memiliki kandungan lemak tinggi, tetapi kuning telur kaya akan High Density Lipoprotein (HDL) atau sering disebut dengan lemak tak jenuh yang sangat baik dikonsumsi. Pada penelitian ini kuning telur masih digunakan sebagai pengemulsi namun kadar penggunaan kuning telur lebih sedikit dibandingkan full fat mayonnaise. Penelitian pembuatan reduced fat mayonnaise ini menggunakan bahan-bahan yang mudah didapat sehingga masyarakat dapat membuat sendiri di rumah serta menjawab akan kebutuhan makanan sehat mengenai mayones yang dikurangi kadar kolesterolnya sehingga dapat memenuhi kebutuhan konsumen yang peduli terhadap pembatasan konsumsi kolesterol. Berdasarkan pernyataan di atas maka pengembangan produk alternatif mayonnaise rendah lemak (reduced fat) ini dapat dimodifikasi dari jenis zat penstabil dan kuning telur yang digunakan. Penelitian ini bertujuan untuk mengetahui penstabil yang baik antara perbandingan CMC (carboxymethyl cellulose), maltodekstrin dan xanthan gum serta jenis kuning telur yang menghasilkan reduced fat mayonnaise dengan sifat fisik, kimia, dan sensoris yang terbaik dan disukai konsumen.

\section{METODE PENELITIAN}

\section{Alat}

Alat yang digunakan dalam penelitian ini antara lain: pH meter (Hanna, negara?), viskometer (Viskometer raypa rp-1, Tiongkok), blender (Miyako, Indonesia), desikator 
(Duran, Jerman), neraca analitik (Vibra, negara?), oven (Memmert, Jerman), spektrofotometri UV-VIS dengan merk Thermo Scientific dengan tipe G10S UV-VIS, dan muffle merk Nabertherm dengan tipe L5/11/C6.

\section{Bahan}

Bahan yang digunakan untuk membuat reduced fat mayonnaise yaitu minyak kedelai, kuning telur ayam kampung, kuning telur ayam petelur, kuning telur ayam omega 3, zat penstabil CMC, maltodekstrin, xanthan gum, gula, garam, merica bubuk, mustard, dan cuka. Reagen kimia yang digunakan antara lain: N-heksan, Reagen $\mathrm{D}$, Reagen $\mathrm{E}$, Reagen $\mathrm{C}, \mathrm{NaOH}$, Glukosa anhidrat, Aquades, Reagen Nelson, Reagen Arsenmolihidrat.

\section{Preparasi Sampel}

\section{Perlakuan Pendahuluan Kuning Telur Reduce Fat Mayonnaise}

Telur ayam diambil kuning telur nya dan dipisahkan dari putih telur, dan cangkangnya, kuning telur di timbang 10 gram, kemudian dipanaskan dalam waterbath suhu $70^{\circ} \mathrm{C} \pm 15$ menit, setelah itu diangkat dan dinginkan (Yuliana, 2015).

\section{Pembuatan Reduce Fat Mayonnaise}

Kuning telur 10 gram dicampur dengan garam 0,5 gram, gula 0,5 gram, merica 0,5 gram, mustard 3 gram dan air $22 \mathrm{ml}$ diblender selama \pm 3 menit, kemudian ditambah zat penstabil (CMC 2,06\%, maltodekstrin 82,43\%, xanthan gum 3,09\%) dan cuka 0,5 ml selanjutnya diblender \pm 4 menit, setelah itu ditambah minyak kedelai $12 \mathrm{ml}$ sedikit demi sedikit dengan blender selama \pm 5 menit selanjutnya dikemas dalam cup dan disimpan refrigerator suhu $9^{\circ} \mathrm{C}$ (Hutapea, Rumasrilin \& Nurminah, 2016)

\section{Pengujian}

Analisis yang digunakan dalam penelitian ini adalah analisis fisika, kimia, dan uji organoleptik. Analisis fisika dan kimia terdiri dari pengukuran $\mathrm{pH}$ (Setiawan, Rahmawan \& Sutardjo, 2015), analisis viskositas (Jacobs,1958), analisis kadar lemak menggunakan metode Soxhlet (Muchtadi \& Sugiyono, 1992), analisis kadar air menggunakan metode termogravimetri (BSN-01.2354.2-2006), analisis protein dengan metode Lowry Folin (Sudarmadji, Haryono \& Suhardi, 1984), analisis kadar gula total dengan metode Nelson Samogyi (Sudarmadji, Haryono \& Suhardi, 1984), dan uji organoleptik dengan metode 
scoring test (Kartika, Hastuti \& Supartono, 1998) meliputi: warna, tekstur lembut, tekstur creamy, flavor dan kesukaan keseluruhan.

\section{Analisis Data}

Penelitian ini menggunakan Rancangan Acak Lengkap (RAL) faktorial, dengan dua faktor yaitu faktor pertama jenis zat penstabil (CMC 2,06 \%, maltodekstrin 82,43\%, xanthan gum 3,09\%) dan faktor kedua jenis kuning telur dengan konsentrasi setiap bahan 20,60\% (kuning telur ayam kampung, kuning telur ayam petelur, kuning telur omega 3). Rancangan tersebut akan memperoleh 9 kombinasi perlakuan masing-masing perlakuan diulang sebanyak dua kali.

Data yang diperoleh dianalisis dengan uji sidik ragam pada jenjang nyata 0,05 . Jika ada beda nyata dilanjutkan uji HSD (honestly significant difference) Tukey untuk mengetahui beda nyata antar perlakuan pada tingkat signifikansi $5 \%$.

\section{HASIL DAN PEMBAHASAN}

\section{Analisis Kimia}

Tabel 1. Rangkuman Hasil Analisis Fisika dan Kimia Pengaruh Konsentrasi Zat Penstabil dan Jenis Kuning Telur terhadap Mutu Reduced Fat Mayonnaise

\begin{tabular}{|c|c|c|c|c|c|c|c|}
\hline \multirow{2}{*}{$\begin{array}{l}\text { Jenis Zat } \\
\text { Penstabil }\end{array}$} & \multirow{2}{*}{$\begin{array}{c}\text { Jenis Kuning } \\
\text { Telur } 20 \%\end{array}$} & \multicolumn{6}{|c|}{ Analisis Kimia } \\
\hline & & $\begin{array}{c}\text { Kadar Air } \\
\%\end{array}$ & $\begin{array}{c}\text { Kadar } \\
\text { Lemak \% }\end{array}$ & $\mathrm{pH}$ & $\begin{array}{c}\text { Viskosita } \\
\text { s }\end{array}$ & $\begin{array}{c}\text { Kadar Gula } \\
\%\end{array}$ & $\begin{array}{c}\text { Kadar Protein } \\
\%\end{array}$ \\
\hline \multirow[t]{3}{*}{ СMC $2,06 \%$} & $\begin{array}{l}\text { Kuning Telur } \\
\text { Ayam } \\
\text { Kampung }\end{array}$ & $36,056^{\mathrm{f}}$ & $53,457^{\mathrm{c}}$ & $4,85^{b}$ & $1,18^{\mathrm{a}}$ & $0,995^{\mathrm{a}}$ & $0,865^{\mathrm{f}}$ \\
\hline & $\begin{array}{l}\text { Kuning Telur } \\
\text { Ayam } \\
\text { Petelur }\end{array}$ & $32,057^{\mathrm{cd}}$ & $60,705^{\mathrm{f}}$ & $4,65^{a b}$ & $2,13^{\mathrm{a}}$ & $0,999^{\mathrm{c}}$ & $0,515^{\mathrm{a}}$ \\
\hline & $\begin{array}{c}\text { Kuning Telur } \\
\text { Omega } 3\end{array}$ & $33,664^{\mathrm{a}}$ & $53,850^{\mathrm{c}}$ & $4,56^{\mathrm{a}}$ & $2,75^{\mathrm{cd}}$ & $0,905^{\mathrm{a}}$ & $0,115^{\mathrm{a}}$ \\
\hline \multirow[t]{3}{*}{$\begin{array}{l}\text { Maltodekstrin } \\
82,43 \%\end{array}$} & $\begin{array}{l}\text { Kuning Telur } \\
\text { Ayam } \\
\text { Kampung }\end{array}$ & $28,684^{\mathrm{a}}$ & $68,175^{\mathrm{h}}$ & $4,80 \mathrm{~b}$ & $1,15^{\mathrm{a}}$ & $0,928^{b}$ & $0,455^{\mathrm{c}}$ \\
\hline & $\begin{array}{l}\text { Kuning Telur } \\
\text { Ayam } \\
\text { Petelur }\end{array}$ & $29,616^{b}$ & $57,513^{c}$ & $4,60^{a b}$ & $1,48^{a b}$ & $1,007^{\mathrm{c}}$ & $0,220^{b}$ \\
\hline & $\begin{array}{c}\text { Kuning Telur } \\
\text { Omega } 3\end{array}$ & $28,651^{a}$ & $45,650^{\mathrm{a}}$ & $4,50^{\mathrm{a}}$ & $3,30^{\mathrm{d}}$ & $0,897^{\mathrm{a}}$ & $0,160^{b}$ \\
\hline \multirow[t]{3}{*}{$\begin{array}{l}\text { Xanthan Gum } \\
3,09 \%\end{array}$} & $\begin{array}{l}\text { Kuning Telur } \\
\text { Ayam } \\
\text { Kampung }\end{array}$ & $32,584^{\mathrm{d}}$ & $57,513^{c}$ & $4,80^{\mathrm{b}}$ & $1,38^{\mathrm{a}}$ & $0,907^{\mathrm{a}}$ & $0,150^{\mathrm{ab}}$ \\
\hline & $\begin{array}{l}\text { Kuning Telur } \\
\text { Ayam } \\
\text { Petelur }\end{array}$ & $31,441^{\mathrm{c}}$ & $62,188^{\mathrm{g}}$ & $4,56^{\mathrm{a}}$ & $1,35^{\mathrm{a}}$ & $1,006^{\mathrm{c}}$ & $0,165^{b}$ \\
\hline & Kuning Telur & $32,292^{f}$ & $52,097^{\mathrm{b}}$ & $4,56^{\mathrm{a}}$ & $2,70^{\mathrm{cd}}$ & $0,929^{\mathrm{a}}$ & $0,170^{\mathrm{b}}$ \\
\hline
\end{tabular}


Omega 3

Keterangan: Rerata yang diikuti huruf yang berbeda pada kolom yang sama menunjukkan beda nyata pada uji Tukey taraf signifikan $5 \%$

\section{Kadar Air .}

Kadar air reduced fat mayonnaise cenderung mempunyai kadar air tinggi disebabkan pembuatan produk emulsi dengan kadar lemak rendah yaitu dengan menurunkan fase terdispersi yaitu minyak dan fase pendispersi air meningkat sehingga kadar air tinggi pada reduced fat mayonnaise. Formulasi dalam pembuatan reduced fat mayonnaise menggunakan karbohidrat sebagai pengental seiring dengan meningkatnya jumlah air yang digunakan maka menurunnya jumlah minyak (Amin, Elbertagy \& Khalil, 2014). Kadar air terendah pada penelitian ini, yaitu $28,651 \%$ diperoleh dari perlakuan zat penstabil maltodekstrin $82,43 \%$ dengan konsentrasi 20,60\% kuning telur ayam omega 3 (Tabel 1). Pada penelitian ini penambahan maltodekstrin $82,43 \%$ dari setiap perlakuan sehingga kadar air rendah pada saat penambahan maltodekstrin. Maltodekstrin juga memiliki sifat higroskopis rendah sehingga tidak mudah menyerap uap air kembali. Menurut SNI 01- 4473-1998 kadar air dalam mayonnaise yaitu maksimal $30 \%$ dengan demikian hasil penelitian ini pada perlakuan kombinasi kuning telur ayam kampung dan kuning telur ayam petelur dan zat penstabil cmc serta xanthan gum belum memenuhi syarat standar mutu mayonnaise dalam SNI (1998).

\section{Kadar Lemak}

Reduce fat mayonnaise merupakan mayones rendah lemak. Dalam penelitian ini kadar lemak pada reduce fat mayonnaise cukup tinggi. Pada Tabel 1. menunjukkan kadar lemak pada penambahan kuning telur omega 3 memliki kadar lemak rendah daripada kuning telur ayam petelur dan kuning telur ayam kampung. Pada data Egg Science and Technology National Institute of Health Research and Development Nutrition (1990) kandungan gizi telur omega 3 per 60 gram yaitu lemak sebesar 3,9 gram. Pada data Direktorat Gizi Departemen Kesehatan (2004) kandungan gizi telur ayam petelur per 100 gram yaitu lemak sebesar 31,9 gram sedangkan data dari Departemen Kesehatan (1981) kandungan gizi telur ayam kampung per 100 gram yaitu lemak sebesar 31,9 gram. Pada penelitian ini dengan penambahan konsentrasi 20,60\% pada kuning telur omega 3 dengan maltodekstrin 82,43\% serta penggunaan minyak kedelai hasilnya 45,650\% memiliki kadar lemak yang paling rendah. Maka penelitian ini sesuai dengan teori bahwa kadar lemak omega 3 rendah dibanding dengan telur ayam petelur dan telur ayam kampung. 


\section{Kondisi pH}

$\mathrm{pH}$ reduced fat mayonnaise tertinggi yaitu 4,85 diperoleh dari zat penstabil CMC 0,48\% dengan kuning telur ayam kampung, sedangkan $\mathrm{pH}$ terendah yaitu 4,50 diperoleh dari zat penstabil maltodekstrin $82,43 \%$ dengan kuning telur ayam omega 3. Penambahan asam cuka pada pembuatan mayones dapat menurunkan pH. (Jaya, Amertaningtyas \& Testiana, 2013). Pencegahan terhadap pertembuhan mikroba pada mayones dapat dilakukan dengan cara menjaga $\mathrm{pH}$ dengan range 2,4-4,5 (Garcia, 2006). Sampel yang berada dalam range nilai $\mathrm{pH}$ tersebut yaitu pada penambahan zat penstabil maltodekstrin $82,43 \%$ dengan kuning telur omega 3 dengan konsentrasi 20,60\% yaitu $\mathrm{pH} 4,5$.

\section{Viskositas}

Viskositas mayones standar dipasaran 3,346 Pa.s (Al Bachir dan Zeinou, 2006). Hasil viskositas reduced fat mayonnaise hanya satu sampel yang mendekati standar mayones yaitu pada perlakuan penambahan maltodekstrin $82,43 \%$ dengan konsentrasi $20,60 \%$ kuning telur omega 3 yaitu 3,30 Pa.s. Viskositas reduced fat mayonnaise terendah pada penambahan jenis kuning telur ayam kampung dan tertinggi pada kuning telur ayam omega 3. Viskositas reduced fat mayonnaise pada penambahan maltodekstrin $82,43 \%$ tinggi disebabkan maltodekstrin dapat meningkatkan total padatan, serta sifatnya mengikat air sehingga menjadikan reduced fat mayonnaise teksturnya kental.

\section{Kadar Gula Total}

Kadar gula total terendah pada penelitian yaitu $0,897 \%$ dari zat penstabil maltodekstrin $82,43 \%$ dengan konsentrasi $20,60 \%$ kuning telur ayam omega 3 sedangkan tertinggi yaitu $1,007 \%$ diperoleh dari zat penstabil maltodekstrin $82,43 \%$ dengan konsentrasi 20,60\% kuning telur ayam petelur. Maltodekstrin sebagai produk hidrolisis pati parsial yang dibuat dengan penambahan asam atau enzim juga merupakan campuran dari oligosakarida, glukosa, maltose dan dekstrin (Luthana, 2008). Menurut SNI 01-4473-1998 kadar gula total dalam mayones yaitu maksimal $4 \%$ dengan demikian hasil penelitian ini memenuhi syarat standar mutu mayones.

\section{Kadar Protein}


Kadar protein reduced fat mayonnaise tertinggi pada penstabil CMC 2,06\% dengan kuning telur ayam kampung dengan konsentrasi 20,60\% yaitu 0,865\%. Berdasarkan penelitian sebelumnya Baktra, Rusdi \& .Mardiah (2016) mengenai penetapan kadar protein dalam telur unggas, hasil kandungan protein rata- rata telur ayam petelur $6,4506 \%$ dan telur ayam kampung 6,9102\%. Menurut SNI 01-4473-1998 kadar protein dalam mayones yaitu minimal $0,9 \%$ dengan demikian hasil penelitian ini tidak memenuhi syarat standar mutu mayones. Pada penelitian ini kadar protein reduce fat mayonnaise menggunakan metode Lowry Follin. Metode Lowry Follin merupakan metode yang banyak digunakan untuk menentukan kandungan protein pada tumbuhan (Harbone, 1987), sehingga kadar protein reduce fat mayonnaise yang berasal dari telur kadar proteinnya rendah saat di analisis. Disarankan mengunakan metode Kjedahl agar kadar protein menjadi lebih besar.

\section{Uji Organoleptik}

Tabel 2. Rangkuman Hasil Uji Organoleptik Pengaruh Konsentrasi Zat Penstabil dan Jenis Kuning Telur terhadap Mutu Reduced Fat Mayonnaise

\begin{tabular}{|c|c|c|c|c|c|c|}
\hline \multirow[b]{2}{*}{ Zat Penstabil } & \multirow[b]{2}{*}{$\begin{array}{c}\text { Jenis Kuning Telur } \\
20,60 \%\end{array}$} & \multirow[b]{2}{*}{ Warna } & \multirow[b]{2}{*}{$\begin{array}{l}\text { Tekstur } \\
\text { Lembut }\end{array}$} & \multicolumn{3}{|c|}{ Uji Organoleptik } \\
\hline & & & & $\begin{array}{l}\text { Tekstur } \\
\text { Creamy }\end{array}$ & $\begin{array}{l}\text { Kesukaan } \\
\text { Keseluruha } \\
\text { n }\end{array}$ & Flavor \\
\hline \multirow{4}{*}{ CMC $2,06 \%$} & $\begin{array}{l}\text { Kuning Telur Ayam } \\
\text { Kampung }\end{array}$ & $2,035^{\mathrm{a}}$ & $4,125^{a}$ & $3,525^{\mathrm{a}}$ & $3,305^{a}$ & $2,585^{\mathrm{a}}$ \\
\hline & $\begin{array}{l}\text { Kuning Telur Ayam } \\
\text { Petelur }\end{array}$ & $2,000^{\mathrm{a}}$ & $3170^{a}$ & $3,595^{\mathrm{a}}$ & $3,190 \mathrm{a}$ & $2,700^{\mathrm{a}}$ \\
\hline & $\begin{array}{l}\text { Kuing Telur Omega } \\
3\end{array}$ & $3,140^{b}$ & $3,740^{\mathrm{a}}$ & $3,175^{\mathrm{a}}$ & $2,665^{a}$ & $2,795^{\mathrm{a}}$ \\
\hline & $\begin{array}{l}\text { Kuning Telur Ayam } \\
\text { Kampung }\end{array}$ & $1,740^{\mathrm{a}}$ & $3,845^{\mathrm{a}}$ & $3,735^{\mathrm{a}}$ & $2,870^{a}$ & $2,880^{\mathrm{a}}$ \\
\hline \multirow{2}{*}{$\begin{array}{l}\text { Maltodekstrin } \\
82,43 \%\end{array}$} & $\begin{array}{l}\text { Kuning Telur Ayam } \\
\text { Petelur }\end{array}$ & $3,645^{b}$ & $3,720^{a}$ & $2,800^{\mathrm{a}}$ & $2,260^{\mathrm{a}}$ & $2,800^{\mathrm{a}}$ \\
\hline & $\begin{array}{l}\text { Kuing Telur Omega } \\
3\end{array}$ & $3,300^{b}$ & $3,970^{\mathrm{a}}$ & $3,465^{\mathrm{a}}$ & $2,610^{\mathrm{a}}$ & $3,215^{\mathrm{a}}$ \\
\hline \multirow{3}{*}{$\begin{array}{l}\text { Xanthan } \\
\text { gum 3,09\% }\end{array}$} & $\begin{array}{l}\text { Kuning Telur Ayam } \\
\text { Kampung }\end{array}$ & $3,415^{\mathrm{a}}$ & $3,970^{a}$ & $3,785^{\mathrm{a}}$ & $3,455^{\mathrm{a}}$ & $3,000^{\mathrm{a}}$ \\
\hline & $\begin{array}{l}\text { Kuning Telur Ayam } \\
\text { Petelur }\end{array}$ & $5,145^{\mathrm{c}}$ & $3,610^{\mathrm{a}}$ & $3,050^{\mathrm{a}}$ & $2,960^{\mathrm{a}}$ & $2,640^{\mathrm{a}}$ \\
\hline & $\begin{array}{l}\text { Kuing Telur Omega } \\
3\end{array}$ & $3,690^{b}$ & $3,885^{\mathrm{a}}$ & $3,650^{\mathrm{a}}$ & $3,455^{\mathrm{a}}$ & $2,960^{\mathrm{a}}$ \\
\hline
\end{tabular}

Keterangan

Warna

: semakin tinggi angka menunjukkan warna yang lebih kuning

Tekstur Lembut

: semakin tinggi angka menunjukkan reduced fat mayonnaise semakin lembut

Tekstur Creamy : semakin tinggi angka menunjukkan reduced fat mayonnaise semakin creamy

Kesukaan Keseluruhan : semakin tinggi angka menunjukkan reduced fat mayonnaise semakin disukai

Flavor : semakin tinggi angka menunjukkan reduced fat mayonnaise 


\section{Warna}

semakin disukai

Pada umumnya penentuan mutu bahan makanan bergantung dari beberapa faktor seperti citarasa, warna, tekstur serta nilai gizinya. Pada uji warna nilai tertinggi $(5,145)$ pada kombinasi kuning telur ayam petelur 20,60\% dan xanthan gum 3,09\% memiliki warna cenderung semakin kuning. Nilai terendah $(1,740)$ pada kombinasi kuning telur ayam petelur $20,60 \%$ dengan maltodekstrin $82,43 \%$.

\section{Tekstur Lembut}

Sifat tekstur yaitu sekelompok sifat fisik yang timbul oleh elemen elemen struktural bahan pangan yang dirasakan oleh perabaan. Pada penelitian ini nilai tertinggi $(4,125)$ pada kombinasi kuning telur ayam kampung 20,60\% dan CMC 2,06\% memiliki tekstur lembut paling tinggi menurut panelis. Sedangkan nilai terendah $(3,170)$ tekstur lembut pada kombinasi kuning telur ayam petelur 20,60\% dengan CMC 2,06\%.

\section{Kesukaan Keseluruhan}

Pemberian penilaian terhadap reduced fat mayonnaise meliputi warna, tekstur lembut, tekstur creamy, flavor,dan kesukaan panelis. Kesukaan panelis satu dengan lainnya cenderung berbeda - beda tergantung selera panelis. Nilai tertinggi $(3,455)$ pada kombinasi kuning telur ayam kampung 20,60\% dengan xanthan gum 3,09\% dan kuning telur ayam omega 3 20,60\% dengan xanthan gum 3,09\% memiliki kesukaan paling tinggi menurut panelis. Sedangkan nilai terendah $(2,260)$ pada kombinasi kuning telur ayam petelur 20,60\% dengan maltodekstrin $82,34 \%$.

\section{Flavor}

Kartika (1988) menyatakan bahwa ada 2 dalam mengamati flavor, pertama melalui indera pembau yang mana rangsangan diterima oleh region alfactoria yaitu bagian atas rongga hidung, yang kedua bisa lewat mulut bagi yang kesulitan mengamati lewat hidung. Kesan dari kedua indera ini mengindikasi flavor dari suatu produk. nilai tertinggi $(3,215)$ pada kombinasi kuning telur ayam omega 3 20,60\% dengan maltodekstrin 82,34\% memiliki kesukaan paling tinggi menurut panelis. Sedangkan nilai terendah $(2,585)$ pada kuning telur ayam kampung 20,60\% dengan CMC 2,06\%.

\section{KESIMPULAN}


Jenis kuning telur omega 3 dengan konsentrasi 20,60\% dan zat penstabil maltodekstrin 82,43\%. Karakteristik reduce fat mayonnaise tersebut yaitu : kadar air 28, 651\%, kadar lemak 45,650\%, pH 4,5, viskositas 3,30 Pa.s, kadar gula total 0,897\%, kadar protein $0,160 \%$. Pada uji organoleptik warna (putih kekuningan) $(3,30)$, tekstur lembut $(3,97)$, tekstur creamy $(3,46)$, kesukaan keseluruhan (paling disukai) $(2,61)$, dan flavor (mayonnaise) $(3,21)$. Pada penelitian ini kadar lemak masih cukup tinggi sehingga belum mencapai tujuan dari pembuatan reduce fat mayonnaise

\section{DAFTAR PUSTAKA}

Al Bachir, M.,\& Zeinou,R. (2006). Effect of gamma iradiation eggs and mayonnaise prepared from irradiation eggs. Journal of Food Safety, 26(1), 346-360.

Amin, M.H.H., Elbeltagy, A.E., Mustafa, M., \& Khalil, A.H. (2014). Development of low fat mayonnaise containing different types and levels of hydrocolloid gum. Journal of Aglimentary Processes and Technologies. 20(1), 54-63

Badan Standarisasi Nasional. (1998). Standar mutu mayonnaise (SNI- 01-4473-1998). Jakarta: Badan Standarisasi Nasional

Badan Standarisasi Nasional. (2006). Cara uji kimia-bagian 2: Penentuan kadar air pada produk perikanan (SNI 01-2354.2.2006). Jakarta: Badan Standarisasi Nasional.

Baktra, D.D.A., Rusdi \& .Mardiah, A. (2016). Penetapan kadar protein dalam telur unggas melalui analisis nitrogen menggunakan metode kjedahl. Jurnal Farmasi Higea, 8(2), 1-8.

Direktorat Gizi Departemen Kesehatan RI. (1981). Komposisi kimia telur ayam Kampung. Jakarta: Direktorat Gizi Departemen Kesehatan RI.

Direktorat Gizi Departemen Kesehatan RI. (2004). Komposisi kimia telur ayam petelur. Jakarta: Direktorat Gizi Departemen Kesehatan RI.

Garcia, KM. (2006). Quality characterization of cholesterol free mayonnaise type spreads containing rice bran oil. Louisiana State University

Harbone, J.B. (1987). Metode fitokimia penentuan cara modern menganalisis tumbuhan. Bandung: Institut Teknologi Bandung

Harrison L.J., \& F.E. Cunningham., 1985. Factors influencing the quality of mayonnaise. J.Food Quality. 8: 1 - 20

Hutapea, C.A., Rusmarilin, H., \& Nurminah, M. (2016). Pengaruh perbandingan zat penstabil dan konsentrasi kuning telur terhadap (reduced fat mayonnaise). Jurnal Rekayasa Pangan dan Pertanian, 4(3), 1-8.

Jacobs, M. B. (1958). The company and technology of food and food product. Newyork: Interscience of Publisher 
Jaya, F., Amertaningtyas, D., \& Testiana, H. (2013). Evaluasi mutu organoleptik (mayonnaise ) dengan bahan dasar minyak nabati dan kuning telur ayam buras. Jurnal Ilmu dan Teknologi Ternak, 8(1), 1-5.

Kartika, B., Hastuti, P., \& Supartono, W., (1988). Pedoman uji inderawi bahan pangan. Yogyakarta : PAU Pangan dan Gizi Universitas Gajah Mada.

Luthana,Y.K. (2008). Maltodekstrin selama pengeringan bubuk dengan menggunakan binder maltodekstrin. Jurnal Penelitian Saintek, 13(1), 1-18

Muchtadi Tien R., \& Sugiono.(1992). Ilmu pengetahuan bahan pangan. Bogor: Institut Pertanian Bogor

National Institute of Health Research and Development Nutrition Centre. (1990). Egg Science and Technology. Bogor: National Institute of Health Research and Development Nutrition Centre

Raymundoa, A., Franco, J.M., Empis, J., \& Sousa, I. (2002). Optimization of the composition of low fat oil in water emulsions stabilized by white lupin protein. J. Amer. Oil. Chem Soc. (79), $783-790$

Setiawan, B., Rachmawan, A.O., \& Sutardjo, D. (2015). Pengaruh penggunaan berbagai jenis kuning telur terhadap emulsi, viskositas dan $\mathrm{pH}$ mayonnaise. Jurnal Peternakan. 4(1), $12-18$.

Sudarmadji, S., Haryono, H., \& Suhardi. (1984). Analisa bahan makanan dan pertanian. Yogyakarta: Liberti

Yuliana, W. (2015). Pengaruh kombinasi suhu, waktu, dan cara pemanasan telur terhadap karakteristik fisik, kimia, dan mikrobiologi (mayonnaise). Semarang: Universitas Katolik Soegijapranata 
